\title{
20-letnia pacjentka z mnogimi powikłaniami zakrzepowo-zatorowymi
}

\section{0-year-old female with multiple thromboembolic complications}

\author{
Anna Oleksiak ${ }^{1}$, Elżbieta Kremis ${ }^{1}$, Piotr Kołsut ${ }^{2}$, Mariusz Kuśmierczyk ${ }^{2}$, Ilona Michałowska ${ }^{3}$, \\ Marek Banaszewski ${ }^{1}$, Anna Konopka ${ }^{1}$, Janina Stępińska ${ }^{1}$ \\ ${ }^{1}$ Klinika Intensywnej Terapii Kardiologicznej Instytutu Kardiologii w Warszawie \\ ${ }^{2}$ Klinika Kardiochirurgii i Transplantologii Instytutu Kardiologii w Warszawie \\ ${ }^{3}$ Zakład Radiologii Instytutu Kardiologii w Warszawie
}

\section{Streszczenie}

Przedstawiono przypadek młodej kobiety z nawracającą obustronną zatorowością płucną i skrzepliną w prawej komorze serca, która wymagała wysokospecjalistycznego leczenia. Współistnienie skrzepliny w prawym sercu i ostrej zatorowości płucnej jest rzadkością, jednak istotnie pogarsza rokowanie pacjentów. Leczenie nadal budzi kontrowersje.

Słowa kluczowe: zatorowość płucna, tromboliza, embolektomia, skrzeplina w prawym sercu, doustne leki przeciwzakrzepowe, niedobór białka C

Folia Cardiologica 2016; 11, 5: 463-468

\section{Wstęp}

Żyına choroba zakrzepowo-zatorowa (VTE, venous thromboembolism) jest jednym z najczęstszych schorzeń układu krążenia (100-200/100 tys./rok) [1]. Najpoważniejszą manifestacją VTE pozostaje ostra zatorowość płucna (PE, pulmonary embolism). Współistnienie ostrej PE i skrzeplin w prawym sercu istotnie pogarsza rokowanie pacjentów i nadal stanowi duże wyzwanie kliniczne $[2,3]$.

\section{Opis przypadku}

\section{Pierwsza hospitalizacja}

Kobieta w wieku 20 lat, z otyłością I stopnia, hospitalizowana od 2 stycznia 2011 roku na oddziale chorób wewnętrznych w szpitalu powiatowym z powodu podejrzenia zapalenia płuc, z 2-tygodniowym wywiadem infekcji górnych dróg oddechowych, 9 stycznia zgłosiła narastającą duszność oraz ból w klatce piersiowej o charakterze opłucnowym. Przedmio- towo zwracała uwage tachykardia zatokowa. W badaniach laboratoryjnych stwierdzono podwyższone stężenie białka C-reaktywnego (CRP, C-reactive protein), bez istotnych odchyleń w zakresie układu białokrwinkowego, wyniki posiewów krwi i plwociny były ujemne, funkcja nerek - prawidłowa, stężenie D-dimerów wynosiło 5,2 $\mu \mathrm{g} / \mathrm{ml}$, a wartości frakcji sercowej kinazy kreatynowej (CK-MB, creatine kinase-myocardial bound) oraz troponiny pozostawały w normie. Na podstawie obrazu angiografii tomografii komputerowej (angio-CT, computed tomography angiography) rozpoznano $P E$, ponadto stwierdzono płyn w jamach opłucnowych oraz obecność skrzepliny o wymiarach $43 \times 25 \times 20 \mathrm{~mm}$ balotującej w prawej komorze. Po nieskutecznym leczeniu fibrynolitycznym rekombinowanym tkankowym aktywatorem plazminogenu (rt-PA, recombinant tissue plasminogen activator), pacjentkę przeniesiono do Instytutu Kardiologii (IK) w celu leczenia kardiochirurgicznego. Wykonano badania obrazowe, stwierdzono utrzymujące się skrzepliny w naczyniach płucnych oraz w prawej komorze (ryc. 1-3).

Adres do korespondencji: lek. Anna Oleksiak, Klinika Intensywnej Terapii Kardiologicznej, Instytut Kardiologii, ul. Alpejska 42, 04-628 Warszawa, e-mail: annaoleksiak.pl@gmail.com 

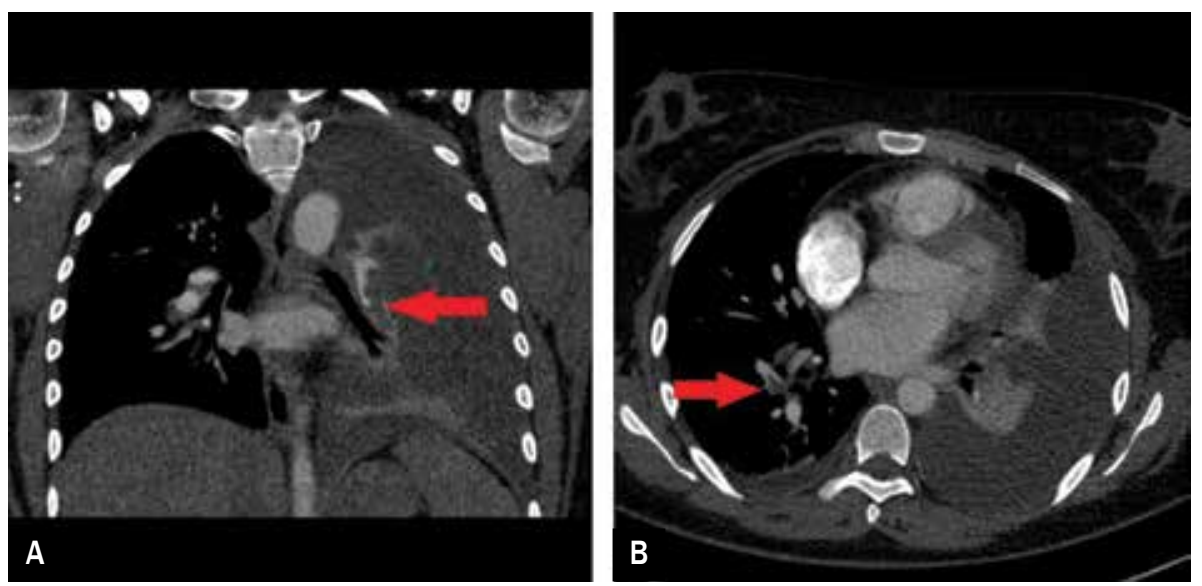

Rycina 1A, B. Angiografia tomografii komputerowej, badanie wykonane przed embolektomią. Strzałki wskazują skrzepliny w lewej tętnicy dolnopłatowej oraz w tętnicach segmentalnych. Obecny płyn w lewej i prawej jamie opłucnowej
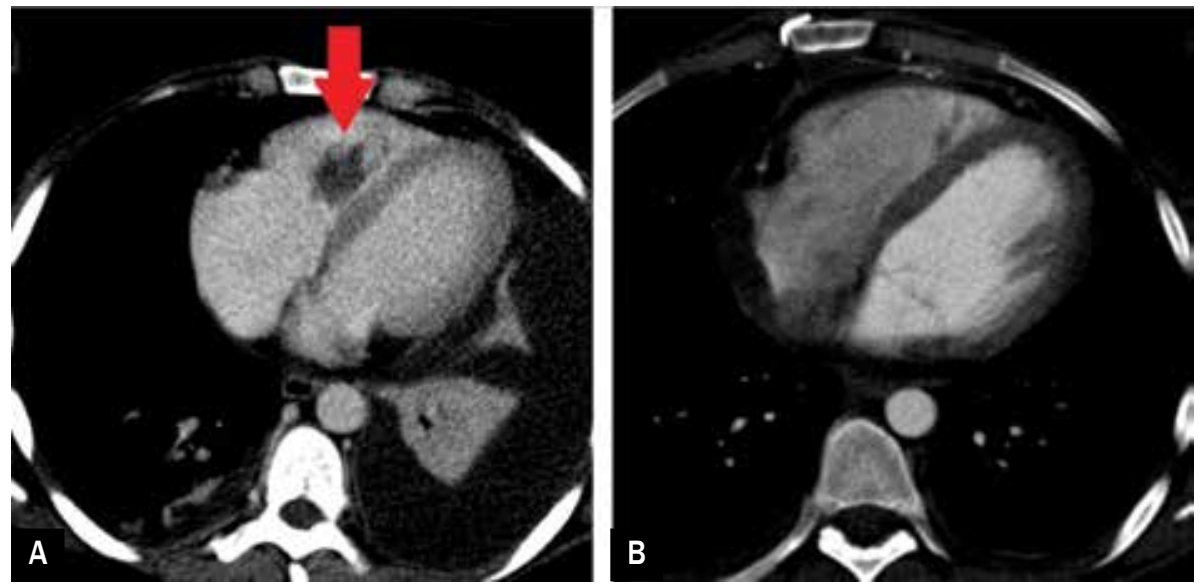

Rycina 2A, B. Angiografia tomografii komputerowej. Widoczna duża skrzeplina w prawej komorze serca (A). Badanie kontrolne, bez patologicznego tworu w jamach prawego serca, widoczne mięśnie brodawkowate (B)
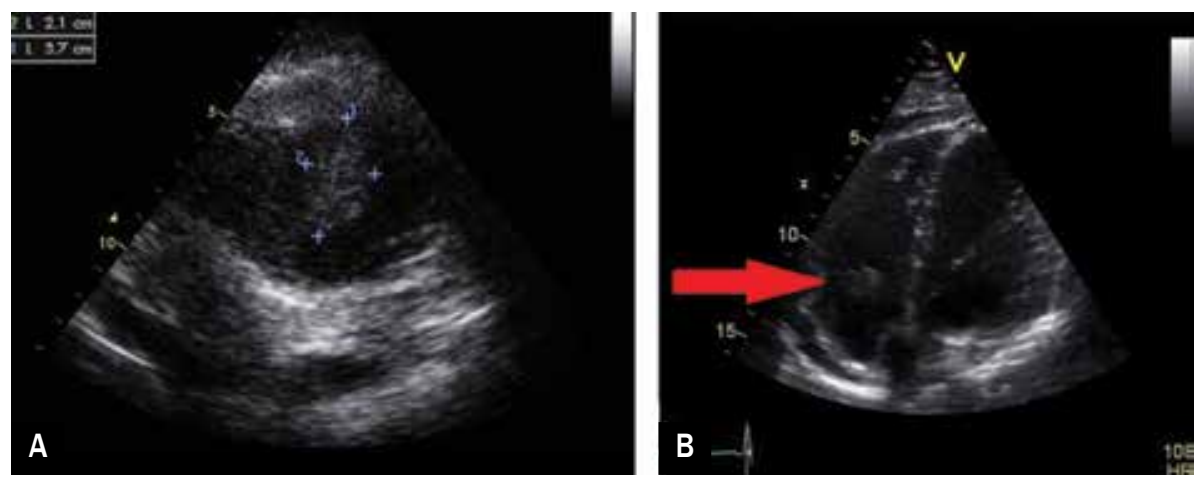

Rycina 3A. Echokardiograficzne badanie przezklatkowe z 11 stycznia. W jamie prawej komory ruchomy, słabo wysycony twór o wymiarach około $37 \times 21$ mm; B. Badanie echokardiograficzne z 21 stycznia z widoczną skrzepliną w prawym przedsionku w okolicy aparatu zastawkowego 
Tabela 1. Wyniki wybranych badań wykonanych w celu ustalenia etiologii żylnej choroby zakrzepowo-zatorowej

\begin{tabular}{|c|c|c|}
\hline Badany czynnik & Wynik & Norma \\
\hline Aktywność białka C (\%) & 55 & $70-140$ \\
\hline Antytrombina III (\%)* & 68,4 & $75-125$ \\
\hline Mutacja czynnika V Leiden** & Ujemny & \\
\hline Mutacja genu protrombiny $20210 * *$ & Ujemny & \\
\hline Przeciwciała cANCA i pANCA & Nie wykryto & \\
\hline Antykoagulant toczniowy & Wątpliwy & \\
\hline Przeciwciała przeciwko beta ${ }_{2}$-glikoproteinie I & Ujemny & \\
\hline Przeciwciała antykardiolipinowe & Ujemny & \\
\hline Przeciwciała przeciwjądrowe & Nie wykryto & \\
\hline Przeciwciała przeciwko endomysium & Nie wykryto & \\
\hline Przeciwciała antymitochondrialne & Nie wykryto & \\
\hline $\begin{array}{l}\text { Antygeny: RNP/Sm, Sm, SS-A, SS-B, Scl-70, PM-Scl, Jo-1, centromer B, } \\
\text { PCNA, dsDNA, nukleosomy, histony, RPP, AMA-M2 }\end{array}$ & Ujemne & \\
\hline Ca125 [j./ml] & 199 & $<35$ \\
\hline $\operatorname{AFP}[\mathrm{ng} / \mathrm{ml}]$ & 1,48 & $<5,10$ \\
\hline $\mathrm{CEA}[\mathrm{ng} / \mathrm{ml}]$ & 0,49 & $<2,5$ \\
\hline HCG [mjm./ml] & $<1,2$ & $<5,0$ \\
\hline Prolaktyna [mjm./l] & 269,95 & $71-566$ \\
\hline Testosteron [ng/dl] & $<10$ & $10-75$ \\
\hline Progesteron [ng/ml] & 0,34 & (Faza folikularna) \\
\hline Estradiol [pg/ml] & $<20$ & 27-122 (faza folikularna) \\
\hline FSH [mjm./ml] & 3,95 & $3,8-8,8$ (faza folikularna) \\
\hline LH [mjm./ml] & 6,45 & 2,1-10,9 (faza folikularna) \\
\hline TSH [jjm./ml] & 1,87 & $0,28-4,3$ \\
\hline ACTH [pg/ml] & 25,2 & $5-46$ \\
\hline
\end{tabular}

W trybie pilnym wykonano embolektomię prawej i lewej tętnicy płucnej oraz usunięto skrzeplinę z prawej komory. W ultrasonografii (USG) żył kończyn dolnych nie stwierdzono zakrzepicy, wynik testu uciskowego USG był obustronnie ujemny, w USG jamy brzusznej nie zaobserwowano skrzeplin w żyle głównej dolnej (IVC, inferior vena cava). W wywiadzie nie było danych na temat nikotynizmu; pacjentka negowała stosowanie antykoncepcji hormonalnej, przy przyjęciu wykluczono ciążę. Poszerzono diagnostykę hormonalną, hematologiczną i immunologiczną (tab. 1). W wykonanych badaniach zwracała uwage obniżona aktywność białka C oraz podwyższone stężenie Ca125 (cancer antigen 125).

Z powodu wczesnego nawrotu PE, mimo stosowania leczenia przeciwzakrzepowego enoksaparyną w dawce terapeutycznej, pacjentka wymagała reoperacji - 21 stycznia wykonano embolektomię lewej tętnicy płucnej, usunięto dwie skrzepliny z prawego przedsionka, tj. większą o wy- miarach $21 \times 17 \times 25$ mm zlokalizowaną w pobliżu ujścia trójdzielnego oraz mniejszą, przytwierdzoną do wolnej ściany przedsionka (ryc. 3-5). Założono filtr do IVC. Kontynuowano leczenie przeciwzakrzepowe enoksaparyną w dawce terapeutycznej. Z powodu niemożności wykluczenia na tym etapie zespołu antyfosfolipidowego dołączono kwas acetylosalicylowy w dawce $75 \mathrm{mg}$. W kolejnych badaniach obrazowych obserwowano narastanie poziomu płynu w jamie osierdzia (ryc. 6). 30 stycznia, z powodu zagrażającej tamponady, chora wymagała perikardiocentezy - ewakuowano $400 \mathrm{ml}$ krwistego płynu. W kontrolnym echokardiograficznym badaniu przezklatkowym nie stwierdzono narastania poziomu płynu. 9 lutego pacjentkę, w dobrym stanie ogólnym, przeniesiono do Instytutu Gruźlicy i Chorób Płuc w celu rozszerzenia diagnostyki, skąd pacjentka została wypisana 18 lutego w dobrym stanie ogólnym; była konsultowana ginekologicznie - wykluczono zmiany rozrostowe w obrębie jajników jako przyczynę stanu nad- 

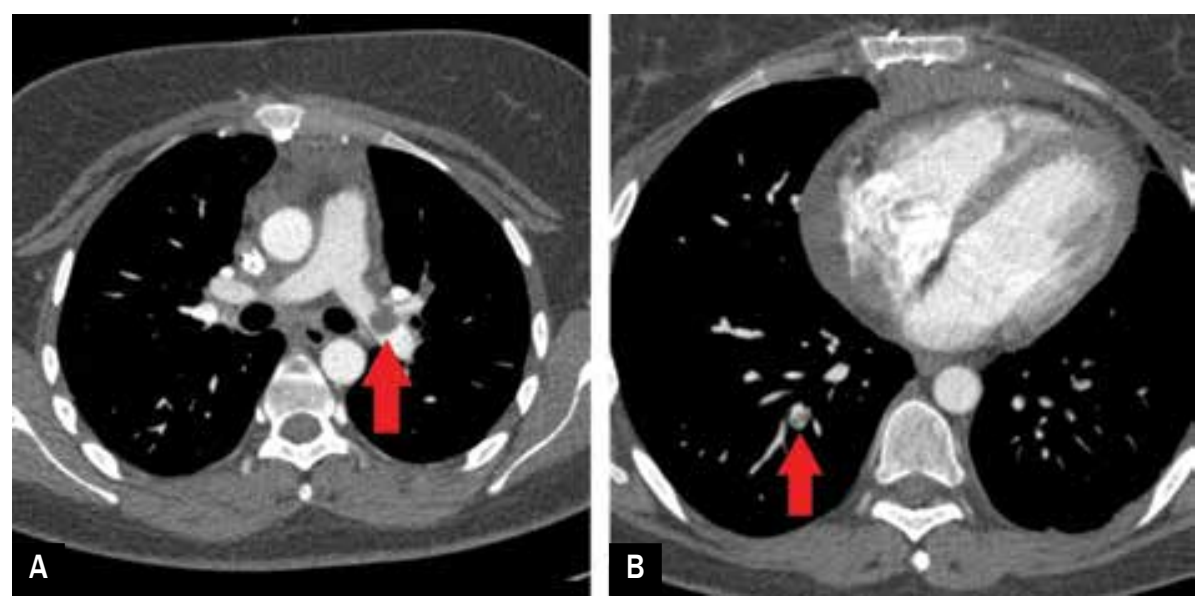

Rycina 4A, B. Angiografia tomografii komputerowej. Nawrót zatorowości płucnej: skrzeplina w lewej tętnicy płatowej przechodząca na tętnicę górnopłatową, skrzepliny w tętnicach segmentalnych prawego płuca

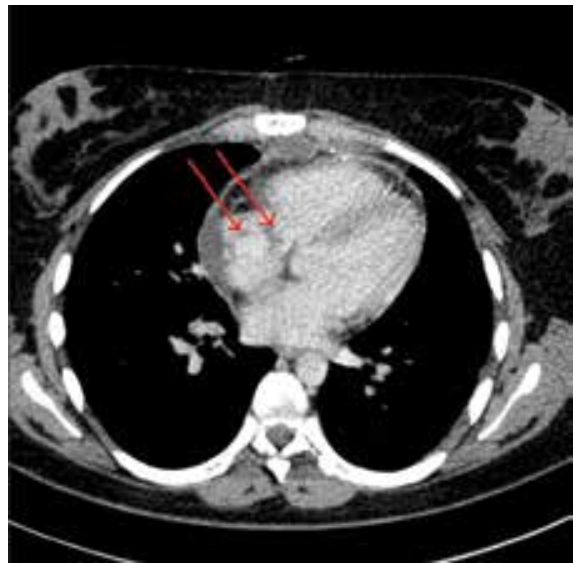

Rycina 5. Angiografia tomografii komputerowej. W prawym przedsionku w okolicy zastawki trójdzielnej hipodensyjna zmiana o wymiarach $21 \times 17 \times 25 \mathrm{~mm}$. Podobna zmiana o wymiarach $11 \times 10 \mathrm{~mm}$ widoczna przy ścianie przednio-bocznej przedsionka

krzepliwości; leczona ASA w dawce 75 mg raz/dobę oraz acenokumarolem $\mathrm{w}$ dawce według wartości międzynarodowego wskaźnika znormalizowanego (INR, international normalized ratio).

\section{Druga hospitalizacja}

26 marca pacjentkę ponownie przyjęto do Kliniki Intensywnej Terapii Kardiologicznej IK z powodu wykrytej w kontrolnym badaniu echokardiograficznym skrzepliny o wymiarach $40 \times 14 \mathrm{~mm}$, związanej z podstawą przedniego płatka zastawki trójdzielnej, wpadającej podczas skurczu do jamy prawej komory, oraz skrzeplin na filtrze wszczepionym do żyły głównej dolnej. W dostępnej dokumentacji ambulatoryjnej od czasu ostatniej hospitalizacji występowały nieterapeutyczne wartości INR (wyniki w zakresie 1,57-2,75). W IK chora leczono heparyną niefrakcjonowaną (UFH, unfractionated

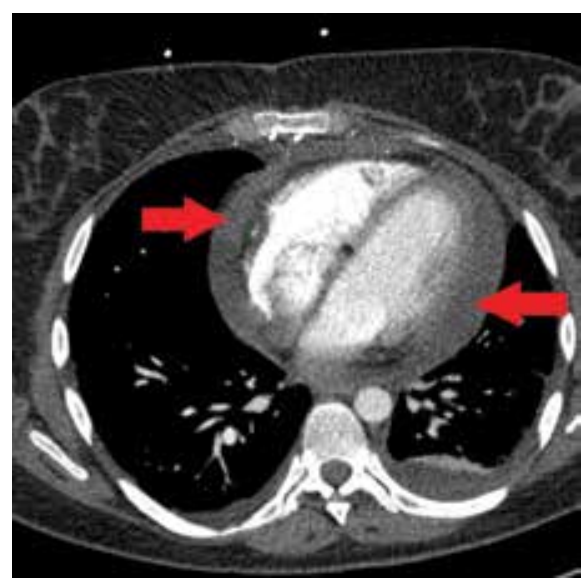

Rycina 6. Angiografia tomografii komputerowej. Narastający poziom płynu w worku osierdziowym

heparin) w dawkach terapeutycznych, uzyskując znaczne zmniejszenie wymiarów skrzepliny w prawym przedsionku. W 7. dobie pobytu ciągły wlew UFH zmieniono na enoksaparynę w dawce terapeutycznej oraz warfarynę pod kontrolą INR. 12 kwietnia w przezprzełykowym badaniu echokardiograficznym nie stwierdzono skrzeplin w jamach serca. Również w badaniu USG zaobserwowano znaczną regresję skrzeplin na filtrze w żyle głównej dolnej. Po blisko miesięcznym pobycie $\mathrm{w}$ IK pacjentkę $\mathrm{w}$ dobrym stanie ogólnym wypisano do domu z zaleceniem stosowania ASA $75 \mathrm{mg}$ raz/dobę oraz warfaryny w dawkach według wartości INR. Zalecono utrzymywanie INR w granicach 2,5-3,0, a w razie niższych wartości stosowanie dodatkowo enoksaparyny w dawce terapeutycznej. Zaplanowano wizytę w poradni Instytutu Hematologii i Transfuzjologii oraz w Klinice Chorób Wewnętrznych i Reumatologii Wojskowego Instytutu Medycznego. 


\section{Omówienie}

Skrzepliny w prawym sercu wciąż dużym wyzwaniem klinicznym

Skrzepliny w prawym sercu (RHT, right heart thrombi) stwierdza się w około 4\% przypadków pacjentów z PE, jednak odsetek ten jest wyższy wśród pacjentów ciężko chorych (do 18\%) [2, 4]. Obecność skrzepliny w prawej komorze w międzynarodowych rejestrach pacjentów z ostrą PE wiązała się z istotnie wyższą śmiertelnością 14-dniową (21 vs. 11\% u osób bez skrzeplin) i 3-miesięczną (odpowiednio $29 \%$ i 16\%) [2]. W przedstawionym przypadku klinicznym leczenie rt-PA okazało się nieskuteczne, a chora wymagała podjęcia pilnego leczenia chirurgicznego. U pacjentów z RHT korzyści terapeutyczne trombolizy w wytycznych opisano jako kontrowersyjne, gdyż wyniki dostępnych badań w tym zakresie są rozbieżne [1]. Należy zatem w każdym przypadku podejmować decyzję, angażując Heart Team zależnie od stanu klinicznego pacjenta i współistniejących obciążeń oraz rokowania [1].

\section{Obniżenie stężenia lub aktywności białka C} a powikłania zakrzepowo-zatorowe

W przedstawionym przypadku zwraca uwage obniżona aktywność białka C (PC, protein C) wynosząca 55\% (norma 70-140\%). Jest to glikoproteina syntetyzowana w wątrobie, w procesie zależnym od witaminy K. Przy udziale białka S pełni rolę inhibitora czynników Va i VIIla, wpływając pośrednio na zmniejszenie produkcji trombiny. Oprócz funkcji przeciwkrzepliwej PC wykazuje aktywność profibrynolityczną, inaktywując inhibitor aktywatora plazminogenu 1 (PAI-1, plasminogen activator inhibitor 1). Niedobór PC może być wrodzony, spowodowany jego zwiększonym zużyciem (jak chociażby w zespole wykrzepiania wewnątrznaczyniowego, w ciężkiej infekcji, sepsie, w ostrej VTE lub zmniejszoną syntezą w związku ze stosowaniem antagonistów witaminy $\mathrm{K}$ (VKA, vitamin $\mathrm{K}$ antagonists) oraz w niewydolności wątroby. Oznaczenie stężenia lub aktywności PC należy wykonywać przed wprowadzeniem terapii VKA. W przypadku rozpoznania powikłań zakrzepowo-zatorowych u młodych osób, oprócz skutecznego leczenia, należy również dążyć do jak najszybszego ustalenia etiologii VTE, uwzględniając najczęstsze trombofilie oraz inne czynniki predysponujące.

\section{Antagoniści witaminy K i NOAC} w profilaktyce PE i zakrzepicy żył głębokich W omawianym przypadku występowały trudności w utrzymaniu terapeutycznych wartości INR podczas leczenia acenokumarolem, co spowodowało wystąpienie nowych powikłań zakrzepowych i kolejną długą hospitalizację. W dostępnych publikacjach wykazano, że stosowanie acenokumarolu wiąże się z 2-krotnie wyższym ryzykiem niestabilności leczenia przeciwzakrzepowego w porównaniu z warfaryną [5]. Zmiana leczenia z acenokumarolu na warfarynę $u$ danego pacjenta może poprawić kontrolę leczenia przeciwkrzepliwego [6]. Łączone leczenie VKA i ASA wiąże się z wyższym ryzykiem krwawień, ale jest postępowaniem z wyboru w sytuacji nawracającej zakrzepicy. Jednocześnie, utrzymując zalecenie leczenia VKA, w takich przypadkach rekomenduje się utrzymywanie INR na wyższym poziomie oraz jego częstszą kontrolę.

Opisaną pacjentkę hospitalizowano w IK przed wprowadzeniem w Polsce do stosowania nowych doustnych antykoagulantów niebędących antagonistami witaminy $\mathrm{K}$ (NOAC, non-vitamin K oral antagonists) dlatego u chorej podczas 2. hospitalizacji dokonano jedynie zamiany VKA. Według aktualnych wytycznych przy istnieniu wskazań do długoterminowej antykoagulacji po 2. epizodzie idiopatycznej PE należy rozważyć stosowanie NOAC (riwaroksabanu, dabigatranu lub apiksabanu) [1]. Powinno się je rozważyć w szczególności u pacjentów, u których trudno uzyskać terapeutyczne, stabilne wartości INR. Autorzy wytycznych nie odnieśli się jednak do stosowania NOAC u pacjentów z VTE i współistniejącą trombofilią, u których również istnieją wskazania do długoterminowej antykoagulacji. Określenie skuteczności NOAC w tej grupie chorych wymaga dalszych badań. Postępy w farmakoterapii przeciwzakrzepowej, które dokonały się w ostatnich latach, pozwalają obecnie na lepszą indywidualizację profilaktyki przeciwzakrzepowej.

\section{Wnioski}

Żylna choroba zakrzepowo-zatorowa stanowi istotny problem kliniczny i wymaga interdyscyplinarnego spojrzenia na pacjenta. Wystąpienie PE u młodych osób, szczególnie poniżej 45. roku życia, skłania do poszukiwania wrodzonych i nabytych przyczyn VTE oraz identyfikacji modyfikowalnych czynników ryzyka. Współistnienie PE i skrzeplin w prawym sercu wiąże się z gorszym rokowaniem i wymaga najczęściej łączonego leczenia heparyną i doustnym antykoagulantem.

\section{Konflikt interesów}

Janina Stępińska: członek grup doradczych, honoraria za wykłady, fundusze na badania naukowe dla firm: Bayer, Boehringer Ingelheim, Orion, Roche Diagnostic. 


\section{Abstract}

We report a case of young female with remittent bilateral pulmonary embolism and thrombus in the right ventricle, who required highly specialized treatment. The coexistence of right heart thrombus with pulmonary thromboembolism is uncommon; however, significantly worsens patients prognosis. Treatment is still controversial.

Key words: pulmonary embolism, thrombolysis, embolectomy, right heart thrombus, oral anticoagulants, protein C deficiency

Folia Cardiologica 2016; 11, 5: 463-468

\section{Piśmiennictwo}

1. Konstantinides S.V., Torbicki A., Agnelli G. i wsp. 2014 ESC Guidelines on the diagnosis and management of acute pulmonary embolism. Eur. Heart J. 2014; 35: 3033-3069, 3069a-3069k.

2. Torbicki A., Galié N., Covezzoli A. i wsp. Right heart thrombi in pulmonary embolism: results from the International Cooperative Pulmonary Embolism Registry. J. Am. Coll. Cardiol. 2003; 41: 2245-2251.

3. Koć M., Lichodziejewska B., Pruszczyk P. Skrzepliny w jamach prawej części serca - nadal duże wyzwanie kliniczne. Przegląd obecnego stanu wiedzy. Kardiol. Pol. 2012; 70: 181-186.
4. Casazza F., Bongarzoni A., Centonze F. i wsp. Prevalence and prognostic significance of right-sided cardiac mobile thrombi in acute massive pulmonary embolism. Am. J. Cardiol. 1997; 79: 1433-1435.

5. Palareti G., Legnani C., Guazzaloca G. i wsp. Risks factors for highly unstable response to oral anticoagulation: a case-control study. Br. J. Haematol. 2005; 129: 72-78.

6. Undas A., Cieśla-Dul M., Żółciński M. i wsp. Switching from acenocoumarol to warfarin in patients with unstable anticoagulation and its effect on anticoagulation control. Pol. Arch. Med. Wewn. 2009; 119: $360-365$. 